\title{
PEMODELAN TINGKAT KEPUASAN MASYARAKAT TERHADAP PROSES PELAYANAN PEMBUATAN SURAT IZIN MENGEMUDI DI SATLANTAS POLRES AMBON MENGGUNAKAN REGRESI LOGISTIK ORDINAL
}

\author{
A. Z. Wattimena ${ }^{1}$, M. W. Talakua ${ }^{2}$, Vanbasten Temartenan ${ }^{3}$ \\ 1,2,3 Jurusan Matematika Fakultas Matematika dan Ilmu Pengetahuan Alam,Universitas Pattimura \\ Jalan Ir. M. Putuhena, Kampus Unpatti, Poka, Ambon, Indonesia \\ e-mail: ${ }^{1}$ az.wattimena@staff.unpatti.ac.id; ${ }^{2}$ ocat_14@yahoo.com; ${ }^{3}$ r.temartenanvanbasten73@gmail.com
}

\begin{abstract}
Abstrak
Kualitas pelayanan pembuatan Surat Izin Mengemudi (SIM) pada kantor Satlantas Polres Ambon dikaji menggunakan analisis regresi logistik ordinal. Tujuan penelitian ini adalah menentukan model yang dapat digunakan untuk menganalisa faktor-faktor yang signifikan berpengaruh terhadap tingkat kepuasan masyarakat dalam proses pelayanan pembuatan SIM di Satlantas Polres Ambon. Sebanyak 102 responden disurvei terhadap empat variabel yang diamati yakni: cara pelayanan, jalur birokrasi, biaya pengurusan, dan informasi pengurusan. Hasil persamaan regresi logistik ordinal dari empat variabel yang diteliti terdapat tiga variabel bebas yang berpengaruh secara signifikan mempengaruhi tingkat kepuasan masyarakat dalam pelayanan pembuatan SIM di Satlantas Polres Ambon. Variabel tersebut adalah cara pelayanan $\left(X_{1}\right)$, biaya pengurusan $\left(X_{3}\right)$, dan informasi pengurusan $\left(X_{4}\right)$. Sehingga model regresi logistik ordinal yang terbentuk untuk tingkat kepuasan masyarakat adalah:

$$
\begin{aligned}
& \operatorname{Logit}\left(Y_{0}\right)=12,932+0,477 \mathrm{X}_{1}+0,327 \mathrm{X}_{3}+0,562 \mathrm{X}_{4} \\
& \operatorname{Logit}\left(Y_{1}\right)=14,968+0,477 \mathrm{X}_{1}+0,327 \mathrm{X}_{3}+0,562 \mathrm{X}_{4} \\
& \operatorname{Logit}\left(Y_{2}\right)=17,031+0,477 \mathrm{X}_{1}+0,327 \mathrm{X}_{3}+0,562 \mathrm{X}_{4}
\end{aligned}
$$

Penelitian ini selain menganalisa kepuasan masyarakat akan tetapi sebagai bahan masukan bagi kantor Satlantas Polres Ambon dalam mengevaluasi kinerja dan mengambil kebijakan untuk dapat terus mengutamakan kepuasan masyarakat.
\end{abstract}

Kata Kunci: kualitas pelayanan, model regresi logistik ordinal, odds ratio.

\section{MODELING OF COMMUNITY SATISFACTION LEVEL TO SERVICE PROCESS IN MAKING DRIVING LICENSE IN SATLANTAS POLRES AMBON USING ORDINAL LOGISTIC REGRESSION}

\begin{abstract}
Quality of service of making Driving License at Satlantas Polres Ambon office is reviewed using ordinal logistic regression analysis. The purpose of this study is to determine the model that can be used to analyze the factors that significantly affect the level of community satisfaction in the process of making Driver's License services in Satlantas Polres Ambon. A total of 102 respondents surveyed to four variables observed namely: way of service, bureaucratic path, cost management, and information management. The results of of ordinal logistic regression equation of four variables under study there is three independent variable the significantly influence the level of public satisfaction in service production of Driver's License at Satlantas Polres Ambon. The variable is way of service $\left(X_{1}\right)$, cost management $\left(X_{3}\right)$, and information management $\left(X_{4}\right)$. So the ordinal logistic regression model that formed for the level of community satisfaction is:

$$
\begin{aligned}
& \operatorname{Logit}\left(Y_{0}\right)=12,932+0,477 X_{1}+0,213 X_{2}+0,327 X_{3}+0,562 X_{4} \\
& \operatorname{Logit}\left(Y_{1}\right)=14,968+0,477 X_{1}+0,213 X_{2}+0,327 X_{3}+0,562 X_{4}
\end{aligned}
$$$$
\operatorname{Logit}\left(Y_{2}\right)=17,031+0,477 X_{1}+0,213 X_{2}+0,327 X_{3}+0,562 X_{4}
$$

This research in addition to analyze the satisfaction of the community but as an input for the Office of Satlantas Polres Ambon in evaluating the performance and take policy to be able to continue to prioritize community satisfaction.
\end{abstract}

Keywords: Service Quality, Ordinal Logistic Regression Model, Odds Ratio. 


\section{Pendahuluan}

Dalam era globalisasi dengan kondisi persaingan yang cukup ketat dan penuh tantangan, aparatur pemerintah dituntut untuk bisa memberikan pelayanan sebaik-baiknya kepada masyarakat dan berorientasi kepada kebutuhan masyarakat. Kualitas pelayanan kepada masyarakat menjadi salah satu indikator dari keberhasilan penyelenggara pemerintah. Negara sebagai organisasi publik, pada dasarnya dibentuk untuk menyelenggarakan pelayanan masyarakat dan bukan dimaksudkan untuk berkembang menjadi besar sehingga mematikan organisasi publik lainnya. Meskipun organisasi publik memiliki ciri-ciri yang berbeda dengan organisasi bisnis, akan tetapi tidak ada salahnya dalam operasionalnya menganut paradigma yang dianut dalam organisasi bisnis, yaitu: efisiensi, efektif, dan menempatkan masyarakat sebagai pengguna jasa yang harus dilayani sebaik-baiknya. Fokus dari dinamika perbaikan kualitas pelayanan terletak pada kepuasan masyarakat yang di sini berperan sebagai pengguna jasa oleh karena itu perlu dipahami hal-hal yang berkaitan dengan masyarakat. Masyarakat dalam konteks ini adalah semua orang yang menuntut suatu organisasi publik untuk memenuhi standart kualitas tertentu dan karena itu memberi pengaruh organisasi publik.

Polres Ambon dan PP Lease merupakan bagian dari Kepolisian Republik Indonesia yang melayani di bidang pemeliharaan dan keamanan, ketertiban masyarakat, penegakan hukum, pengayoman dan pelayanan pada masyarakat. Berdasarkan data yang diperoleh dari Satlantas Polres Ambon memperlihatkan bahwa setiap tahunnya ada peningkatan jumlah dalam pengurusan SIM. Masyarakat atau pemakai jasa layanan akan menuntut pelayanan yang lebih baik dari organisasi publik. Pada dasarnya suatu organisasi yang bergerak dalam bidang jasa, kunci keberhasilan terletak pada layanan yang diberikan kepada masyarakat. Harus disadari pula bahwa pelayanan dan kepuasan masyarakat sebagai pengguna jasa merupakan suatu aspek vital dalam rangka mempertahankan eksistensi suatu organisasi. Meskipun demikian untuk mewujudkan kepuasan secara menyeluruh tidaklah mudah. Apalagi masyarakat sekarang lebih kritis dan telah memahami haknya. Masyarakat akan selalu memperhatikan haknya dan dengan semaksimal mungkin akan menggunakanya untuk mendapatkan semua kepuasan kebutuhan. Salah satu metode statistik yang dapat digunakan untuk menganalisis faktor-faktor yang signifikan berpengaruh terhadap tingkat kepuasan masyarakat terhadap proses pembuatan SIM adalah teknik Pemodelan Regresi Logistik Ordinal.

Analisis regresi logistik ordinal merupakan suatu analisis regresi yang digunakan untuk memodelkan hubungan antara variabel bebas dengan variabel respon yang berskala ordinal. Berdasarkan permasalahan di atas, maka penelitian ini digunakan untuk mengetahui model peluang tingkat kepuasan masyarakat berdasarkan faktor-faktor yang signifikan berpengaruh. Berdasarkan faktor-faktor itu, pihak Kepolisian memiliki prioritas yang harus dilaksanakan untuk meningkatkan kualitas pelayanannya terhadap masyarakat. Dengan demikian kepuasan masyarakat dapat dipenuhi secara maksimal dan tujuan proses pembuatan SIM dapat tercapai.

\section{Tinjauan Pustaka}

\subsection{Uji Validitas dan Reliabilitas}

Validitas adalah ketepatan atau kecermatan suatu instrumen dalam mengukur apa yang akan diukur. Uji Validitas dilakukan dengan cara mengkorelasikan masing-masing skor item dengan skor total. Item-item pertanyaan yang berkorelasi signifikan dengan skor total menunjukan item-item tersebut valid. Jika nilai $p$ value kurang dari $\alpha$, maka item-item pertanyaan dikatakan valid.

Uji reliabilitas digunakan untuk mengetahui konsistensi alat ukur, apakah alat pengukur yang digunakan dapat diandalkan dan tetap konsisten jika pengukuran tersebut diulang. Uji reliabilitas menggunakan metode Alpha (Cronbach’s). Suatu kuesioner dikatakan reliabel jika nilai Alpha Cronbach’s lebih dari 0,6.

\subsection{Analisis Regresi}

Analisis regresi adalah analisis statistik yang digunakan untuk melihat pengaruh antara dua atau lebih variabel. Hubungan variabel tersebut bersifat fungsional yang diwujudkan dalam suatu model matematis yaitu variabel independen dengan tujuan untuk memprediksi nilai rata-rata variabel dependen didasarkan pada nilai variabel independen yang telah diketahui. Istilah 'regresi' pertama kali diperkenalkan oleh seorang ahli yang bernama Fancis Galton pada tahun 1886. 


\subsection{Analisis Regresi Logistik}

Analisis regresi logistik adalah metode regresi yang menggambarkan hubungan antara beberapa variabel prediktor dengan sebuah variabel respon dikotomus atau biner. Variabel respon $(Y)$ pada metode regresi logistik dikatakan biner karena terdiri atas dua kategori yaitu 0 dan 1 . Analisis regresi logistik biner bertujuan untuk memperoleh hubungan antara $X i$ dan $P i$ (probabilitas kejadian yang diakibatkan oleh $X i$ ). Berapapun nilai $x$ bila disubtitusikan kedalam fungsi logistik hasilnya akan berkisar antara 0 dan 1 . Regresi logistic digunakan untuk analisis data respon kategorik (nominal atau ordinal) dengan variabel-variabel bebas kontinu dan kategorik. Berdasarkan jumlah kategori respon, regresi logistik dapat dibedakan menjadi dua, yaitu regresi logistik dikotomus dan polikotomus [1].

Regresi logistik dikotomus adalah suatu analisis regresi yang digunakan untuk mengambarkan hubungan antara variabel respon dengan sekumpulan variabel prediktor, dimana variabel responnya berskala biner atau dikotomus dengan variabel prediktor berskala dikotomus maupun polikotomus. Variabel dikotomus adalah variabel yang memiliki 2 kemungkinan (sukses atau gagal), sedangkan variabel polikotomus adalah variabel yang memiliki lebih dari dua kemungkinan [1].

Variabel respon biasanya disimbolkan dengan $Y$, sedangkan variabel prediktor disimbolkan dengan $X$. Variabel respon $(Y)$ mengikuti distribusi Bernoulli dengan fungsi probabilitas:

$$
f\left(y_{i}\right)=p^{y_{i}}(1-p)^{1-y_{i}}, y_{i}=0,1
$$

Distribusi dari variabel respon ini merupakan pembeda antara regresi logistik dengan regresi linear. Pada regresi linear variabel responnya diasumsikan berdistribusi normal, sedangkan untuk variabel respon pada regresi logistik bersifat kategorikal. Adapun fungsi logistik adalah sebagai berikut:

$$
f(x)=\frac{1}{1+e^{-x}},-\infty<x<\infty
$$

Untuk $x=-\infty$ maka $\lim _{x \rightarrow-\infty} f(x)=0$ sedangkan $x=\infty$ maka $\lim _{x \rightarrow \infty} f(x)=1$. Dengan melihat kemungkinan nilai $f(x)$ yang berkisar antara 0 dan 1 , ini menunjukkan bahwa regresi logistik sebenarnya menggambarkan probabilitas terjadinya suatu kejadian

\section{Gambar 1. Kurva fungsi logistik}

Untuk mempermudah maka digunakan notasi $\pi(x)=E(y \mid x)$ untuk menyatakan rata-rata bersyarat dari $Y$ jika diberikan nilai $X$. Bentuk model regresi logistik adalah (Agresti, 1990):

$$
\pi(x)=\frac{e^{\left(\beta_{0}+\beta_{1} X\right)}}{1+e^{\left(\beta_{0}+\beta_{1} X\right)}}
$$

\subsection{Regresi Logistik Ordinal}

Regresi logistik ordinal adalah suatu analisis regresi yang digunakan untuk memodelkan hubungan antara variabel bebas dengan variabel respon yang berskala ordinal. Dalam regresi logistik ordinal ini, variabel respon ( $Y$ ) berskala ordinal dengan $J$ kategori dan $X^{\prime}=\left(X_{1}, X_{2}, \cdots, X_{p}\right)$ adalah variabel bebas $(X)$, maka peluang dari variabel respon kategori ke- $j$ pada variabel bebas $X$ tertentu dapat dinyatakan dengan $p[Y=j \mid x]=\pi_{j}(x)$ dan peluang kumulatifnya [5] adalah:

$$
P[Y \leq j \mid x]=\pi_{1}(x)+\cdots+\pi_{j}(x)
$$

Model logit kumulatif didefinisikan dengan: 


$$
\begin{aligned}
L_{j}(x) & =\operatorname{logit} P[Y \leq j \mid x] \\
& =\log \left[\frac{P[Y \leq j \mid x]}{1-P[Y \leq j \mid x]}\right] \\
& =\log \left[\frac{\pi_{1}(x)+\cdots+\pi_{j}(x)}{\pi_{j+1}(x)+\cdots+\pi_{J}(x)}\right] \\
& =\alpha j-x \beta
\end{aligned}
$$

Dimana $j=1, \cdots, J-1$ dan $\alpha_{1}, \cdots, \alpha_{J-1}$ adalah threshold model serta $\beta$ merupakan vektor koefisien regresi.

Metode pendugaan parameter yang dapat digunakan pada regresi logistik ordinal diantaranya adalah dengan metode kemungkinan maksimum. Metode ini dapat dilakukan jika antara amatan yang satu dengan yang lain diasumsikan saling bebas. Fungsi kemungkinannya dapat dinyatakan sebagai [5].

Analisis regresi ordinal yang telah dijelaskan sebelumnya adalah analisis regresi ordinal dengan fungsi hubung logit atau sering disebut regresi logistik ordinal.

Tabel 1. Fungsi Hubung Pada Regresi Ordinal

\begin{tabular}{cc}
\hline Fungsi Hubung & Bentuk Fungsi \\
\hline Logit & $\log \left[\frac{\pi}{1-\pi}\right]$ \\
Complementary log-log & $\log (-\log (1-\pi))$ \\
Negative log-log & $-\log (-\log (\pi))$ \\
Probit & $\Phi^{-1}(\pi)$ \\
Chauchit & $\tan (\operatorname{phi}(\pi-0,5))$ \\
\hline
\end{tabular}

a) Uji Serentak

Uji serentak ini dilakukan yaitu untuk mengetahui signifikansi parameter $\beta$ terhadap variabel respon secara keseluruhan. Uji serentak disebut juga uji model Chi-Square, dilakukan sebagai upaya memeriksa peranan variabel prediktor dalam model secara bersama-sama. Pengujian signifikansi parameter tersebut mengunakan statistik uji G, dimana statistik uji G mengikuti distribusi Chi-Square dengan derajat bebas satu. Hipotesis yang digunakan:

$$
\begin{aligned}
& \mathrm{H}_{0}: \beta_{1=} \beta_{2=\cdots=}=\beta_{p} \\
& \mathrm{H}_{1} \text { : minimal ada satu } \beta_{j} \neq 0, \text { dengan } j=1,2, \ldots, p .
\end{aligned}
$$

Statistik uji yang digunakan adalah statistik uji G atau Likelihood Ratio Test:

$$
\begin{aligned}
G^{2} & =-2 \ln \left[\frac{l_{1}}{l_{0}}\right] \\
& =-2 \ln \frac{\left(\frac{n_{1}}{n}\right)^{n_{1}}\left(\frac{n_{0}}{n}\right)^{n_{0}}}{\sum_{i=1}^{n} \hat{\pi}_{i}^{y i}\left(1-\hat{\pi}_{i}\right)^{(1-y i)}}
\end{aligned}
$$

dengan:

$$
n_{1}=\sum_{i=1}^{n} y_{i} ; n_{0}=\sum_{i=1}^{n}\left(1-y_{i}\right) ; n=n_{1}+n_{0}
$$

dimana:

$n_{1}=$ banyaknya observasi yang berkategori 1

$n_{0}=$ banyaknya observasi yang berkategori 0

$n$ = banyaknya observasi $\left(n_{1}+n_{0}\right)$

$l_{1}=$ Likelihood tanpa variabel prediktor tertentu

$l_{0}=$ Likelihood dengan variabel prediktor tertentu 


\section{b) Uji Individu (Uji Parsial)}

Untuk menguji pengaruh setiap $\beta_{j}$ secara individual. Hasil pengujian secara individual akan menunjukkan apakah suatu variabel prediktor layak untuk masuk dalam model atau tidak [1]. Hipotesis yang digunakan adalah:

$$
\begin{aligned}
& H_{0}: \beta_{k}=0 \\
& H_{1}: \beta_{k} \neq 0, k=1,2, \ldots, p ; p=\text { jumlah prediktor dalam model }
\end{aligned}
$$

Statistik Uji yang digunakan adalah Uji Wald:

Dimana:

$$
W=\frac{\widehat{\beta}_{l}}{S E_{i}\left(\widehat{\beta}_{l}\right)}
$$

$\widehat{\beta_{l}}$ : nilai koefisien regresi logistik untuk variabel ke-i

$S E_{i}:$ standard error variabel ke-i

\section{c) Uji Kesesuaian Model}

Menurut [6], terdapat statistik uji yang digunakan untuk menguji kesesuaian model regresi logistik yaitu Goodness of Fit dengan hipotesis sebagai berikut:

$H_{0}:$ Model sesuai

$H_{1}:$ Model tidak sesuai

Statistik Uji:

$$
\chi^{2}=\sum_{j=1}^{J} \frac{\left(y_{j}-m_{j} \phi_{j}\right)^{2}}{m_{j} \phi_{j}\left(1-\phi_{j}\right)}
$$

dengan $j=1,2,3, \ldots J$

dimana,

$\mathrm{y}_{j}$ : variabel respon ke- $j$

$\mathrm{m}_{j}$ : banyaknya observasi yang memiliki nilai $\phi_{j}$

$\phi_{j}$ : peluang kumulatif

Kriteria penolakan: tolak $\mathrm{H}_{0}$ apabila $\chi^{2}{ }_{\text {hitung }}>\chi_{(d b, \alpha)}^{2}$ atau $p$-value $<\infty$.

\section{d) Menginterprestasi Koefisien Parameter}

Pada regresi logistik ordinal, terdapat juga interpretasi koefisien model regresi logistik ordinal yang merupakan inferensi dan pengambilan keputusan berdasarkan koefisien yang diestimasi. Koefisien tersebut menggambarkan slope atau perubahan pada variabel terikat per unit perubahan pada variabel bebas. Untuk menginterpretasi koefisien parameter, digunakan Odds ratio $(\psi)$. Odds ratio didefinisikan sebagai ratio odds untuk $x=1$ terhadap odds untuk $\mathrm{x}=0$, yang dapat dituliskan dalam persamaan berikut [5]:

\subsection{Kualitas Pelayanan}

$$
\psi=\frac{\pi(1) / 1-\pi(1)}{\pi(0) / 1-\pi(0)}
$$

Kualitas pelayanan merupakan salah satu yang menjadi perhatian utama bagi masyarakat umum yang diselenggarakan oleh pemerintah dan penyedia jasa public. Kualitas pelayanan publik yang diselenggarakan oleh instansi pemerintahan pada saat ini menjadi sorotan bahkan menjadi tuntutan masyarakat. Persoalan yang sering dikritik masyarakat atau penerima layanan adalah persepsi terhadap kualitas yang melekat pada seluruh aspek pelayanan [8] adalah:
1) Kesesuaian dengan persyaratan
2) Kecocokan untuk pemakaian
3) Perbaikan berkelanjutan
4) Bebas dari kerusakan/cacat 
5) Pemenuhan kebutuhan pelanggan sejak awal dan setiap saat

6) Melakukan segala sesuatu secara benar

7) Sesuatu yang bisa membahagiakan pelanggan

Menurut pendapat diatas, diketahui bahwa kualitas pelayanan mencakup berbagai faktor yaitu kualitas pelayanan publik merupakan hasil interaksi aspek pelayanan, sumber daya manusia, starategi dan pengguna jasa. Menurut [8] mengatakan bahwa kepuasan pelanggan adalah tingkat perasaan seseorang setelah membandingkan kinerja atau atau hasil yang dirasakan dibandingkan dengan harapannya. Setiap pelanggan tentu menghendaki kepuasan dan menerima suatu layanan sedangkan ukuran keberhasilan penyelenggaraan pelayanan ditentukan oleh tingkat kepuasan penerima layanan.

Berdasarkan penjelasan diatas maka pengertian kualitas pelayanan adalah terpenuhinya karakteristik suatu konsep pelayanan yang mencakup seluruh aspek pelayanan dan tolak ukur kualitas pelayanan itu adalah dapat member kepuasan kepada para pelanggan atau penerima layanan.

\section{Hasil dan Pembahasan}

\subsection{Variabel Yang Digunakan}

Dalam penelitian ini variabel prediktor $(X)$ yang digunakan untuk analisis regresi logistik ordinal adalah sebagai berikut:

1. $\mathrm{X}_{1}$ : Cara Pelayanan

2. $\mathrm{X}_{2}$ : Jalur Birokrasi

3. $\mathrm{X}_{3}$ : Biaya Pengurusan

4. $\mathrm{X}_{4}$ : Informasi Pengurusan

\subsection{Hasil Penelitian}

\subsubsection{Uji Validitas}

Pengujian validitas menggunakan rumus product moment dari Pearson dengan menghitung korelasi antar masing-masing skor item pertanyaan tiap variabel dengan skor totalnya. Jika skor item tersebut berkorelasi positif dengan skor total item dan lebih tinggi dari korelasi antar item berarti menunjukan kevalidan instrumen tersebut. Hipotesis yang digunakan yaitu:

$$
\begin{aligned}
& H_{0} \text { : item atau pertanyaan tidak valid } \\
& H_{0} \text { : item atau pertanyaan valid }
\end{aligned}
$$

Dengan menggunakan software SPSS diperoleh hasil sebagai berikut:

\begin{tabular}{|c|c|c|c|}
\hline Item / Pertanyaan & P-Value & $\alpha$ & Keterangan \\
\hline X11 & 0,000 & \multirow{16}{*}{0,05} & Valid \\
\hline X12 & 0,000 & & Valid \\
\hline X13 & 0,000 & & Valid \\
\hline X14 & 0,000 & & Valid \\
\hline X21 & 0,000 & & Valid \\
\hline X22 & 0,000 & & Valid \\
\hline X23 & 0,000 & & Valid \\
\hline X24 & 0,000 & & Valid \\
\hline X31 & 0,000 & & Valid \\
\hline X32 & 0,000 & & Valid \\
\hline X33 & 0,000 & & Valid \\
\hline X34 & 0,000 & & Valid \\
\hline X41 & 0,000 & & Valid \\
\hline X42 & 0,000 & & Valid \\
\hline X43 & 0,000 & & Valid \\
\hline X44 & 0,000 & & Valid \\
\hline
\end{tabular}

Tabel 2. Hasil Pengujian Validitas 
Berdasarkan Tabel 2, terlihat bahwa dengan menggunakan $\alpha$ sebesar 5\% maka diperoleh semua item/pertanyaan memiliki nilai $p$-value lebih kecil dari 0,05 sehingga tolak $H_{0}$. Hal ini menunjukan bahwa semua item/pertanyaan valid.

\subsubsection{Uji Reliabilitas}

Pengujian reliabilitas dalam penelitian ini menggunakan koefisien Cronbach's Alpha. Hasil pengujian reliabilitas dengan menggunakan software SPSS adalah sebagai berikut.

Tabel 3. Hasil Pengujian Reliabilitas

\begin{tabular}{|l|c|c|}
\hline \multicolumn{1}{|c|}{ Variabel } & Alpha & Keterangan \\
\hline Cara Pelayanan & 0,675 & Reliabel \\
\hline Jalur Birokrasi & 0,608 & Reliabel \\
\hline Biaya Pengurusan & 0,689 & Reliabel \\
\hline Informasi Pengurusan & 0,605 & Reliabel \\
\hline
\end{tabular}

Berdasarkan Tabel 3, terlihat bahwa nilai koefisien Cronbach's Alpha untuk semua variabel lebih dari 0,6. Hal ini menunjukan bahwa kuesioner telah reliabel.

\subsubsection{Pemodelan Regresi Logistik Ordinal}

Selanjutnya akan dilakukan pemodelan tingkat kepuasan masyarakat terhadap proses pembuatan SIM dengan menggunakan model regresi logistik ordinal. Hasil estimasi parameter dengan menggunakan software SPSS disajikan sebagai berikut.

Tabel 4. Hasil Estimasi Parameter Model

\begin{tabular}{|c|c|c|c|c|}
\hline Variabel & Koefisien & SE. Koefisien & P-Value & Odds Ratio \\
\hline Respon $[\mathrm{Y}=0]$ & 12,932 & 1,915 & 0,000 & \\
\hline$[\mathrm{Y}=1]$ & 14,968 & 2,049 & 0,000 & \\
\hline$[\mathrm{Y}=2]$ & 17,031 & 2,272 & 0,000 & \\
\hline $\begin{array}{ll}\text { Prediktor } \mathrm{X}_{1} \\
\end{array}$ & 0,477 & 0,167 & 0,004 & 1,611 \\
\hline $\mathrm{X}_{2}$ & 0,213 & 0,131 & 0,104 & 1,237 \\
\hline $\mathrm{X}_{3}$ & 0,327 & 0,158 & 0,039 & 1,386 \\
\hline $\mathrm{X}_{4}$ & 0,562 & 0,148 & 0,000 & 1,754 \\
\hline
\end{tabular}

\subsubsection{Uji Serentak}

Pengujian secara serentak dilakukan untuk mengetahui apakah keseluruhan variabel bebas (prediktor) yang digunakan memiliki pengaruh terhadap variabel tak bebas (respon). Dalam pengujian serentak, uji signifikansi model yang dipakai adalah uji likelihood ratio test. Adapun hipotesis yang akan diuji adalah sebagai berikut.

$H_{0}: \beta_{1}=\beta_{2}=\cdots=\beta_{j}=0 ; J=1,2, \ldots, 4$ (tidak ada pengaruh sekumpulan variabel prediktor terhadap variabel respon)

$H_{1}: \beta_{j} \neq 0 ; J=1,2, \ldots, 4$ (terdapat minimal satu variabel prediktor berpengaruh terhadap tingkat kepuasan masyarakat)

Keputusan tolak $\mathrm{H}_{0}$ pada tingkat signifikan sebesar $\alpha=0,05$ jika statistik uji $G>\chi_{(d b, \alpha)}^{2}$ atau $p-$ value $<\alpha$. Hasil Pengujian likelihood ratio test ditunjukkan pada tabel berikut.

Tabel 5. Pengujian likelihood ratio-test

\begin{tabular}{|c|c|c|}
\hline G & DF & P-value \\
\hline 188,000 & 4 & 0,000 \\
\hline
\end{tabular}

Berdasarkan Tabel 5, diperoleh informasi bahwa pengujian dengan likelihood ratio test menunjukkan nilai statistik Uji G sebesar 188,000 dan nilai $p$-value $=0,000$ yang lebih kecil dari $\alpha=0,05$ artinya keputusan yang diambil adalah tolak $H_{0}$. Hal ini berarti terdapat satu atau lebih variabel bebas yang berpengaruh secara signifikan terhadap tingkat kepuasan masyarakat. Langkah selanjutnya adalah melakukan pengujian signifikansi parameter secara parsial. 


\subsubsection{Uji Parsial}

Dari pengujian secara serentak diketahui bahwa terdapat satu atau lebih variabel bebas yang berpengaruh terhadap variabel respon. Oleh karena itu untuk mengidentifikasi variabel bebas apa saja yang berpengaruh signifikan terhadap variabel respon maka dilakukan pengujian parsial terhadap masing-masing variabel bebas. Dalam pengujian parsial, statistik uji yang digunakan adalah statistik uji Wald. Hipotesis yang digunakan adalah sebagai berikut.

$$
\begin{aligned}
& H_{0}: \beta_{j}=0 ; j=1,2, \ldots, 4 \text { (tidak ada pengaruh variabel prediktor yang di uji terhadap tingkat } \\
& \quad \text { kepuasan masyarakat) } \\
& H_{1}: \beta_{j} \neq 0 ; j=1,2, \ldots, 4 \text { (terdapat pengaruh variabel prediktor yang di uji terhadap tingkat kepuasan } \\
& \quad \text { masyarakat) }
\end{aligned}
$$

Keputusan tolak $H_{0}$ pada tingkat signifikan sebesar $\alpha=0,05$ jika statistik uji $W>Z_{\alpha / 2}$ atau $p$-value $<\alpha$.

Berdasarkan Tabel 4, terlihat bahwa terdapat satu variabel prediktor yang signifikan mempengaruhi tingkat kepuasan masyarakat dengan tingkat kepercayaan sebesar 95\% yaitu jalur birokrasi $\left(\mathrm{X}_{2}\right)$, karena memiliki nilai $p$-value yang lebih kecil dari $\alpha=0,05$. Dari pengujian secara parsial maka model regresi logistik yang diperoleh adalah sebagai berikut.

$$
\begin{aligned}
& \operatorname{Logit}\left(Y_{0}\right)=12,932+0,477 X_{1}+0,327 X_{3}+0,562 X_{4} \\
& \operatorname{Logit}\left(Y_{1}\right)=14,968+0,477 X_{1}+0,327 X_{3}+0,562 X_{4} \\
& \operatorname{Logit}\left(Y_{2}\right)=17,031+0,477 X_{1}+0,327 X_{3}+0,562 X_{4}
\end{aligned}
$$

\subsubsection{Uji Kesesuaian Model}

Pengujian kesesuaian model ini bertujuan untuk mengetahui apakah persamaan model yang dibentuk telah sesuai atau tidak. Adapun hipotesis yang diuji adalah sebagai berikut.

$$
\begin{aligned}
& H_{0}: \text { Model sesuai } \\
& H_{1}: \text { Model tidak sesuai }
\end{aligned}
$$

Keputusan tolak $H_{0}$ jika statistik uji $\chi^{2}{ }_{\text {hitung }}{ }^{>} \chi^{2}{ }_{(d b, \alpha)}$ atau $p-$ value $<\alpha$. Tabel 6 (cek tabel sebelumnya) dibawah ini menunjukkan pengujian kesesuain model menggunakan statistik uji Deviance.

Tabel 6. Uji Kesesuaian Model

\begin{tabular}{|c|c|c|c|}
\hline \multicolumn{4}{|c|}{ Goodness-of-Fit Tests } \\
\hline Method & Chi-Square & DF & P \\
\hline Deviance & 179,447 & 254 & 1,000 \\
\hline
\end{tabular}

Berdasarkan Tabel 6, diperoleh informasi bahwa nilai $\chi^{2}{ }_{\text {hitung }}$ sebesar 179,667 dan nilai $p$-value yakni 1,000 lebih besar dari $\alpha=0,05$, sehingga keputusan yang diambil adalah terima $H_{0}$ yang artinya model regresi logistik ordinal untuk tingkat kepuasan masyarakat yang dihasilkan sudah sesuai.

\subsubsection{Interprestasi Model Regresi Logistik ordinal}

Jika model regresi logistik ordinal telah diuji dan hasil modelnya baik dan signifikansinya nyata maka data tersebut dapat di interpretasikan dengan menggunakan uji odds ratio.

Tabel 7. Nilai Odds Ratio

\begin{tabular}{|l|c|c|}
\hline \multicolumn{1}{|c|}{ Variabel } & Koefisien & Odds Ratio \\
\hline Cara Pelayanan & 0,477 & 1,611 \\
\hline Jalur Birokrasi & 0,213 & 1,237 \\
\hline Biaya Pengurusan & 0,327 & 1,386 \\
\hline Informasi Pengurusan & 0,562 & 1,754 \\
\hline
\end{tabular}


1) Odds ratio Cara Pelayanan $\left(X_{1}\right): \psi=e^{0,477}=1,61$. Hal ini dapat diartikan bahwa peluang masyarakat merasa sangat puas pada cara pelayanan 1,61 kali dibanding dengan masyarakat yang merasa tidak puas.

2) Odds ratio Jalur Birokrasi $\left(X_{2}\right): \psi=e^{0,213}=1,23$. Hal ini dapat diartikan bahwa peluang masyarakat merasa sangat puas pada cara pelayanan 1,23 kali dibanding dengan masyarakat yang merasa tidak puas.

3) Odds ratio Biaya Pengurusan $\left(X_{3}\right): \psi=e^{0,327}=1,38$. Hal ini dapat diartikan bahwa peluang masyarakat merasa sangat puas pada cara pelayanan 1,38 kali dibanding dengan masyarakat yang merasa tidak puas.

4) Odds ratio Informasi Pengurusan $\left(X_{4}\right): \psi=e^{0,562}=1,75$. Hal ini dapat diartikan bahwa peluang masyarakat merasa sangat puas pada cara pelayanan 1,75 kali dibanding dengan masyarakat yang merasa tidak puas.

\section{Kesimpulan}

Berdasarkan hasil analisis data dan pembahasan, maka kesimpulan dalam penelitian yaitu bahwa dengan menggunkan model regresi logistik ordinal yang melibatkan data 102 orang masyarakat yang mengurus SIM maka dari empat variabel bebas yang dianalisis terdapat satu variabel bebas yang signifikan mempengaruhi tingkat kepuasan masyarakat dalam pelayanan pembuatan SIM di Satlantas Polres Ambon. Variabel tersebut yaitu jalur birokrasi $\left(\mathrm{X}_{2}\right)$. Sehingga model regresi logistik ordinal yang terbentuk untuk tingkat kepuasan masyarakat adalah sebagai berikut.

$$
\begin{aligned}
& \operatorname{Logit}\left(Y_{0}\right)=12,932+0,477 X_{1}+0,327 X_{3}+0,562 X_{4} \\
& \operatorname{Logit}\left(Y_{1}\right)=14,968+0,477 X_{1}+0,327 X_{3}+0,562 X_{4} \\
& \operatorname{Logit}\left(Y_{2}\right)=17,031+0,477 X_{1}+0,327 X_{3}+0,562 X_{4}
\end{aligned}
$$

\section{Daftar Pustaka}

[1] A. Agresti, Categorial Data Analysis, New York: John Wiley \& Sons. Inc, 1990.

[2] A. Agresti, Categorial Data Analysis, Second Edition, New York: John Wiley \& Sons, Inc., 2002.

[3] A. Lisna and H. R. V., "Analisa Tingkat Kepuasan Masyarakat Dalam Pelayanan Pembuatan Surat Izin Mengemudi di Satlantas Polres Tapanuli dengan Regresi Logistik,” Jurnal Saintia Matematika, pp. 435-444, 2013.

[4] A. Widarjono, Ordinal Logistik Regression, New York: Wiley \& Sons, 2010.

[5] D. L. S. Hosmer, Applied Logistic Regression, Second Ed, Singapura: John Wiley \& Sons. Inc, 2000.

[6] D. W. Hosmer and S. Lemeshow, Applied Logistic Regression, First Edition, New York: John Wiley \& Sons, Inc., 1989.

[7] D. Kleinbaum and M. Klein, Logistic Regression, New York: Springer-Verlag, 2002.

[8] F. Tjiptono, Perspektif Manajemen dan Pemasaran, Yogyakarta: Andy offset, 1996.

[9] M. Albana, "Aplikasi Regresi Logistik Ordinal Untuk Menganalisa Tingkat Kepuasan Pengguna Jasa Terhadap Pelayanan di Stasiun Jakarta Kota,” Universitas Pakuan, Bogor, 2013. 
